\section{Tanzilya Nigmatullina,}

Doctor of Political Sciences, Associate Professor,

Head of the Department of Political Science, history,

theory of State and Law, Director of the Bashkir Institute

of Social Technologies (branch) of the Academy of Labor

and Social Relations (the city of Ufa),

vova-velc@yandex.ru

\section{Architecture of History education: challenges of the time}

The article is a response to the need in changing the system of History education in the country, that is caused by the challenges of the time. Particular attention is paid to the reasons that lead to a decrease in students' interest in history, as well as the problems of history education in the world. The author presents the results of a sociological survey, the best practices of the university, aimed at preserving historical memory, the formation of an all-Russian civic identity, moral and ethical values and an active life position of children and youth, as well as fostering a careful and respectful attitude to the historical and cultural heritage of the peoples of the Russian Federation and the world.

Keywords: History education; historical consciousness; folk history; «Observatory» program; citizenship; project work.

\title{
Станислав Сулимов
}

\section{Образование как инструмент культурной экспансии}

Статья посвящена анализу роли школьного образования в экспансионистских процессах. Опираясь на современные отечественные исследования, автор определяет сущность экспансии и колониализма как одного из ее видов. Разграничивая такие формы экспансии как политическая, экономическая и культурная (религиозный прозелитизм относится к культурной экспансии), автор полагает, что организация начального образования в колониях гарантирует прочность результатов колониальной экспансии, в какой бы форме она ни происходила. Но если учреждаемая система образования не будет гармонировать с культурной картиной мира потенциальных учеников, то ее применение окажется бесполезным. Автор рассматривает применение школьного образования в процессе колонизации на широком круге примеров от Сибири до индейских резерваций.

Ключевые слова: экспансия; колонизация; культурная картина мира; христианизация; школьное образование; православная церковь; рабство; седентаризация.

Современный глобальный мир, как и любой иной социальный порядок, создан в процессе различных экспансий. Общества расширяли свои границы, усиливали собственное влияние, и в результате их борьбы сложилась единая мировая система. Однако было бы ошибкой считать, что на этом процесс мирового социального развития завершился. До тех пор, пока люди остаются самими собой, и индивиды, и группы будут стремиться к изменению своего положения, влиять друг на друга и бороться друг с другом. Эта

Сулимов

Станислав Игоревич

кандидат философских

наук, дочент, Воронежский

государственный университет

(Воронеж),sta-sulimov@ya.ru борьба не обязательно вооруженная, более того, немалая ее часть проходит за школьными партами. В данной работе мы рассмотрим школьное образование как инструмент процесса экспан- 
сии и на основе исторических примеров установим область применения этого инструмента.

Процесс экспансии представляет собой определяющее влияние, которое общество-экспансионист оказывает на жизнедеятельность других обществ (субъект экспансии оказывает преобладающее влияние на свои объекты). При этом экспансия вовсе необязательно связана с насилием. Отечественный исследователь Б.Н. Шапталов отмечает: «Экспансионистская система строится не по шаблону, а исходя из четко доминирующих в социуме целей. Если у «вас» цель захват земель, то будет одна экспансионистская система, если завоевание рынка высокотехнологичной продукции - другая, если доминирование на рынке нефти - третья и т. д. В таком целеполагании заключено качественное отличие одной экспансионистской системы от другой» [11, с. 121]. Например, помимо политической экспансии, экспансия бывает экономической, предполагающая доминирование в торговле и поэтому старающаяся избегать военных акций, ведь война - враг торговли. Экспансия может быть и культурной, ярче всего выражающейся в религиозном прозелитизме. Разновидность экспансии - колонизация, предполагающая создание нового очага обитания (колонии) при сохранении прежнего (метрополии) [3, с. 36]. Как и любая другая экспансия, колонизация имеет различные формы, зависящие от конкретных целей. Например, религиозная колонизация не акцентирует внимание на политических проблемах и старается дистанцироваться от политики. Примером религиозной метрополии может служить Московская патриархия, в роли колонии которой выступает Патриарший экзархат Западной Европы, с которым вместе Патриархия образует единую систему, именуемую Московский патриархат. При этом религиозная метрополия и ее колония находятся в разных государствах, а их адепты подчиняются различным юридическим законам.

Особенность колонизации в том, что колония и метрополия, будучи связаны между собой, не могут быть подвергнуты унификации. Колония не пустошь, которую выходцы из метрополии могли бы заселить и перенести на нее свои привычные порядки. Это иной по отношению к метрополии субъект, который во время колониальной экспансии был объектом, но за годы сосуществования и взаимодействия с метрополией становится де-факто или де-юре обособленным. И метрополия оказывается в двойственном положении: с одной стороны, покушаться на своеобразие колонии нельзя, иначе она не сможет выполнять свою функцию в колониальной системе, но в то же время колониальное своеобразие не должно переходить пределы, удерживающие колониальную систему в равновесии. Яркий пример таких отношений - британская колониальная политика в Северной Америке в XVIII в. Колониям Восточного побережья позволялось иметь самоуправление, чуть позже англичане были вынуждены допустить созыв единого колониального ополчения, и все это никак не мешало тринадцати колониям выполнять свою экономическую функцию в рамках Британской империи. Поскольку цель англичан была именно экономическая, то колониальные губернаторы мирились с деятельностью выборных магистратов и колониальных ассамблей. Но однажды реалии жизни колониального общества вступили в серьезное противоречие с нуждами метрополии, колонисты потребовали представительства в парламенте (то есть уравнивания прав метрополии и колонии), а на такой шаг Британия пойти не могла. Последовало сначала экономическое, а затем и военное противостояние, уничтожившее колониальные отношения между Британией и ее вчерашними 
тринадцатью колониями, превратившимися в Соединенные Штаты Америки.

Чтобы не допустить подобного сценария развития событий, общество-экспансионист уделяет внимание формированию картины мира и духовному развитию жителей колоний. Причем речь необязательно идет о колониях в политическом смысле. Тот же процесс благотворен и для культурной экспансии. Например, чтобы русская литература могла обрести читателей в Юго-Западной Азии, необходимо либо обеспечить ее перевод на местные языки, либо каким-то образом содействовать изучению будущими читателями русского языка.

Именно поэтому важная задача функционеров метрополии - организация школьного (а позднее и высшего) образования в колониях. Только так метрополия может решить две важнейшие проблемы: снабдить жителей периферии знаниями и умениями, полезными для сотрудничества с метрополией, и примирить их с занимаемым ими в колониальной системе положением. Важно, что образование играет такую определяющую роль только в колониальной системе, прочие же виды экспансии могут обойтись без него. Например, выгнать жителей захваченных земель или угрозами принудить их к выплате дани можно и без каких-либо объяснений, а вот организовать долгосрочное неравноправное взаимодействие такими методами не получится.

Организация метрополией образования в колониях имеет давнюю историю. Например, немецкий историк T. Моммзен описывает, как римские завоеватели устраивали в галльских городах лицеи для преподавания латыни, греческого языка, риторики и юриспруденции сыновьям кельтской аристократии [6, с. 115]. Традиционная галльская система ценностей настолько отличалась от римской, что принудить галлов к экономиче- скому и политическому партнерству в приказном порядке не представлялось возможным. Скорее всего, побежденные на поле боя кельты даже не поняли бы, что от них требуется. Однако благодаря функционированию римских лицеев меньше через сто лет, прошедших с завоевания Галлии, ее жители уже не отделяли себя от империи и охотно сотрудничали с римской администрацией на всех предложенных ею поприщах.

Метод, каким действовали римские колонизаторы в Галлии, в различных вариациях применяли на протяжении Средневековья и Нового времени все наиболее удачливые субъекты колониальной экспансии. Рассмотрим такую «образовательную колонизацию»на примере из русской истории - обратимся к становлению российской колониальной системы в Сибири.

Захваченные и подвергшиеся быстрому освоению русскими переселенцами в XVI-XVII вв. сибирские земли представляли собой для Москвы в первую очередь экономический интерес. Вот как описывает цели и задачи русской колонизации Сибири В.К. Андриевич: «Тот мотив, который вызвал первое знакомств русских людей с местностями, лежащими между Уральскими горами и р. Обью, - нажива - проходит через всю историю завоевания Сибири и служит побудительной причиной к постепенному надвиганию русских колонизаторов Сибири вплоть до берегов Великого океана и до настоящих южных границ ее с Китаем. <...> Следовательно, первой побудительной причиной, вызвавшей появление русских людей в Приобских, Сибирских землях, была: для частного лица - барыш, для правительства - сбор дани» [1, с. 9-10]. До тех пор, пока в метрополию поступали пушнина и деньги, корона закрывала глаза на методы, которыми это богатство добывалось.

В результате Сибирь наводнили любители легкой наживы, в том числе донские и волжские казаки, пленные 
поляки и литовцы, европейские наемники и даже преступники, отправленные в пожизненную ссылку и почти сразу же «приставленные к делу» [2, с. 190]. Такой колонист стремился в первую очередь позаботиться о собственном финансовом благополучии, и царская администрация Тобольска не была в этом отношении исключением. Воеводы и сменившие их в XVIII в. губернаторы охотно присваивали себе часть выжимаемых из местных жителей налоговых средств и не запрещали этого делать своим помощникам всех рангов и уровней, если корона не терпела убытков и не выказывала неудовольствия. Легко представить, какие в таком колониальном обществе установились нравы: с одной стороны, деспотичная, стоящая над законом власть чиновников, поддерживаемых партнерами-купцами и вооруженной силой казаков, а с другой - полная нравственная деградация служилого и податного населения. Г.Ф. Миллер в красках описывает пьянство, азартные игры, незаконные поборы, торговлю людьми и многоженство, процветавшие среди русских переселенцев и обеспечивавшиеся за счет постоянного силового подавления местного населения [5, с. 72-73].

Можно ли было построить долгосрочные иерархические отношения между колонией и метрополией на таких началах? Разумеется, нет. Сибирь ждала либо освободительная война, которая увенчалась бы успехом, как только коренные народы освоили бы огнестрельное оружие, либо сецессия, возглавляемая состоятельным сибирским купечеством, не желающим делиться с короной своими доходами. Интеграция аборигенного населения в русское общество была возможна, и корона на ней настаивала, но процесс этот шел только на бумаге. Ведь коренные жители плохо понимали русский язык, не умели читать и писать порусски и ничего не знали о тех правах, которые им предоставляло российское законодательство. Обычно в таких сценариях ситуацию сглаживает вмешательство церкви, и история знает немало тому примеров. Однако Русскую православную церковь в Сибири нередко представляли клирики, по каким-то причинам отправленные из метрополии «с глаз долой». Присланных в Сибирь священников и монахов было мало, и в большинстве своем они получили такое тяжелое назначение по причине пьянства и иной неспособности к пастырскому служению [2, с. 267]. Такие священнослужители не могли не только проповедовать, но и подавать пример элементарной порядочности единоверцам.

Ситуация изменилась с назначением на митрополичью кафедру Тобольска в 1702 г. святителя Филофея (Лещинского). Новый владыка был выпускником Киево-Могилянской академии, образованным и сведущим в богословских, философских и хозяйственных вопросах, до дальнего назначения занимавшим должность эконома Киево-Печерской Лавры. Оказавшись в Сибири и верно оценив специфику местных отношений и состояние тамошнего духовенства, митрополит горячо занялся организацией школьного образования, открыв на церковные средства в Тобольске духовную школу. Какие задачи он хотел решить? Во-первых, христианский прозелитизм невозможен без знакомства паствы со Священным Писанием, а для этого новообращенным христианам необходимо уметь читать. Во-вторых, святитель Филофей с самых первых дней своего пребывания в Тобольске взял курс на пополнение рядов духовенства клириками «туземного» происхождения. Интеграцию коренных сибирских жителей в русское общество, на которой правительство настаивало абстрактно, митрополит осуществил фактически. 
Вот как характеризует деятельность владыки Филофея Е.Н. Поселянин: «Из детей инородческих выбирались способные мальчики и посылались в мужские монастыри и архиерейский Тобольский дом. Там учили их грамоте и Закону Божьему, готовя их к священническому званию» [7, с. 153]. Священники-«инородцы» пополнили ряды сибирского духовенства, в скором времени присылка клириков из Центральной России стала ненужной. Конечно, митрополиту Филофею пришлось столкнуться со многими трудностями: он совершал рискованные миссионерские путешествия по долине Оби; нехватка учителей вынуждала святителя вести уроки лично; но в итоге система архиерейских школ в Сибири эффективно функционировала.

Сменивший владыку на митрополичьей кафедре в 1711 г. святитель Иоанн (Максимович) продолжил дело своего славного предшественника и, будучи талантливым церковным писателем и очень образованным человеком, развернул Тобольскую архиерейскую школу в духовное училище. Оба святителя также пользовались авторитетом в глазах русских колонистов, так как отличались щедрой милостыней и неподдельным интересом к личным проблемам своей паствы. Благодаря их усилиям к концу XVIII в. с неприкрытой дискриминацией местного населения было покончено. Входя в духовное сословие, ханты, манси, якуты и т. д. автоматически получали правовой статус русских священников, и попытка оказать на них давление приравнивалась законом к нападению на духовное лицо. Кроме того, грамотные клирики местных национальностей без труда могли написать жалобу в столицу или отстоять права земляков в суде. Высокий уровень преподавания, заданный святителями, создал образовательным учреждениям ореол престижа. Даже в XIX в., когда уже не- мало студентов-сибиряков училось в университетах Москвы и Санкт-Петербурга, мечтой сибирских областников было открытие университета в Иркутске [8, с. 304-305]. То есть, даже планируя ограничение влияния метрополии в Сибири, незадачливые сепаратисты не отрицали ценность образования российского образца.

Зададимся вопросом: решила ли организация тобольскими святителями школьного образования в Сибири возложенные на нее задачи? Безусловно. Если коснуться первоочередных задач (самовоспроизводство сибирского клира, обучение местного населения русскому языку), то эффект стал очевидным для всех уже в середине XVIII в. Если же попытаться осмыслить русскую колониальную политику в Сибири на протяжении XVIII-XIX вв., то становится ясно: эффект оказался более разносторонним и долговременным, чем рассчитывали его основатели. Школьное, а затем и высшее образование, построенное в колонии и метрополии по одному образцу, настолько сплотило сибирских колонистов и местное население с обществом метрополии, что даже гражданская война (1917-1922 гг.) не породила в Сибири влиятельных сепаратистских движений. Более того, именно благодаря единой системе образования Сибирь дала русской культуре такие имена, как И.У. Басаргин (1930-1976), В.П. Астафьев (1924-2001), В.Г. Распутин (1937-2015), многих других известных авторов.

Но может ли обходиться продолжительная и удачная колонизация без целенаправленного устройства колониального образования? Может быть, причины успеха или неудачи экспансии носят исключительно политический или экономический характер? К примеру, перенимать культуру или религию бедных, трусливых, мно- 
гократно разбитых на поле боя соседей никто не станет. Обратимся к историческому опыту такой колониальной державы как Франция.

Одной из самых развитых и упорядоченных французских колоний XVIII в. была Сан-Доминго (ныне - peспублика Гаити). Располагаясь на крайне плодородном острове, колония обеспечивала метрополии бесперебойный доход и снабжение такими дорогими продуктами, как табак, кофе и сахар. Экономическое благосостояние острова строилось на товарном плантационном хозяйстве, в котором широко использовался рабский труд. Чернокожих невольников тысячами привозили из южной Нигерии и современного Бенина, принуждали к работе в поле и господском доме, а отношения между различными расовыми и социальными группами населения колонии регулировал так называемый Черный кодекс. Это был крайне противоречивый правовой документ, который, с одной стороны, обязывал рабовладельцев заботиться о невольниках и даже наставлять их в католической вере, но, с другой стороны, нормы Черного кодекса не признавали африканского раба личностью. Например, побег квалифицировался как кража, то есть раб как бы украл сам себя у хозяина. Точно также кодекс обязывал рабовладельцев признавать своих внебрачных детей от невольниц и предоставлял таким детям по праву рождения неотчуждаемую свободу, но в то же время для мулатов существовал ряд нерушимых правовых ограничений, ставящих их ниже белых колонистов. Если учесть, что главной задачей французской колониальной экспансии в Сан-Доминго было получение максимальной прибыли, становятся ясны цели Черного кодекса: его нормы должны были обеспечить бесперебойную работу плантаций, не давая рабам шанса отказаться от труда и при этом защищая их от чрезмерного произвола хозяев. Невольники должны были при- носить прибыль, а не служить средством для удовлетворения чьих-то садистских наклонностей.

Апартеид, лежащий в основе Черного кодекса, делал невозможной интеграцию чернокожих (как рабов, так и свободных) в колониальное общество, а островное положение колонии препятствовало массовым побегам и возникновению мятежных формирований. Обычно в такой безвыходной ситуации католическая церковь брала на себя заботу о социально обделенной общественной группе и собственными усилиями создавала искусственные условия, в которых гонимые могли бы приобщиться к христианству и безбоязненно вести регламентированный клиром образ жизни. Таковы были францисканские миссии на Юкатане и иезуитские редукции в Парагвае, и со своими задачами они справлялись достаточно эффективно.

Однако во французских колониях на Антильских островах церковь хоть и имела своих представителей, но была в административном порядке лишена права заниматься миссионерской деятельностью среди невольников. Колониальные чиновники строго запрещали клирикам открывать школы для чернокожих детей, а проповедь затруднялась тем, что хозяева почти никогда не брали рабов с собой в церковь. Вот как описывает духовно-просветительскую и педагогическую работу с невольниками в Сан-Доминго Дж. К. Ингрэм: «Рабов не только не обучали, но даже прямо было за прещено само обучение, «потому что оно отнимало у раба время и могло внушить ему только гордость». Христианская религия в руках колонистов говорила рабам только о необходимости повиноваться своим господам. По свидетельству одного из миссионеров, губернатор колонии присвоил себе право над духовными лицами: он указывал, чем должны ограничиваться их обязанности, как они должны проповедовать евангельское уче- 
ние, и прямо изгонял тех, которые не сообразовывались с церковными правилами, составленными в его канцеляриях» [4, с. 187]. В результате такого подхода чернокожие жители колонии не только не приобщились к европейскому образу жизни, но составили свое собственное общество, ценности которого строились по принципу отторжения всего, что считали хорошим колонисты европейского происхождения. Так, в христианстве они видели утонченное лицемерие, а производительный труд считали уделом бесхарактерных, слабых духом людей. Несколько поколений черных невольников и дискриминируемых мулатов прожили именно с такими убеждениями, тщательно скрываемыми от хозяев и господ. Итог не заставил себя ждать: в 1791 г., пользуясь революционной неразберихой во Франции, рабы восстали, подвергли истреблению белое население колонии, а католические церкви - осквернению и разрушению. Духовно-идеологическим знаменем восстания стал синкретический культ вуду, в котором западноафриканская религиозность косметически дополняется христианской обрядностью. Получив независимость в 1804 г., республика Гаити целенаправленно дистанцировалась от любого европейского наследия, и даже в середине ХХ в. некоторые ее президенты призывали «покончить с колониальным прошлым».

Итак, мы рассмотрели два примера колониальной экспансии, в которых доминировали экономические цели, но субъекты-экспансионисты придавали различное значение школьному и высшему образованию. И в Сан-Доминго XVIII в., и в Сибири XVI-XVIII вв. сложились устойчивые режимы экономической колонизации, в которых часть трудового населения против своей воли была поставлена в приниженное, зависимое положение. В обоих случаях колониальный режим поддер- живался вооруженной силой, способной подавить любые протесты. Но в русскую колонизацию вмешалась православная церковь, привнеся в экономическое освоение элемент религиозного прозелитизма. Учрежденное свт. Филофеем (Лещинским) духовное образование стало тем социальным лифтом, который позволил представителям местного населения войти в колониальное общество, а некоторым из них - даже получить статус клириков. Поэтому уже в XIX в. фактор вооруженного принуждения уже не играл серьезной роли: русская Сибирь выковалась за школьной партой.

Иной стала судьба французской колонии, в которой все внимание администрации и предпринимателей сосредоточилось исключительно на экономической выгоде, а любые иные аспекты колониальной жизни попросту игнорировались. Местное общество не имело и не обрело никакого интегрирующего начала (ни единой системы ценностей, ни общих знаний, ни объединяющей религии), поэтому в юридически единой колонии исподволь сформировались два социума, системы ценностей которых противоречили друг другу. Как только колониальная администрация утратила возможность поддерживать сложившийся порядок силой, более многочисленное общество чернокожих невольников и освобожденных атаковало и истребило малочисленных, но привилегированных колонистовфранцузов. С основания колонии до обретения ею независимости успело пройти почти полтора века, и за это время единой социальной системы так и не сложилось. Возможно, одна из причин этого заключается именно в нежелании привилегированной части населения заниматься образованием неполноправных жителей.

Всегда ли результативна организованная метрополией для колоний система образования? Нет. Образова- 
ние, как и привнесенная извне система воспитания, возымеет положительный әффект только в том случае, если окажется совместимым с культурной картиной мира учеников и воспитанников. Например, нелегко прививать послушание людям, в системе ценностей которых скромность и смирение не считаются добродетелями. То же самое можно сказать и о знаниях, умениях и навыках, которым ученики и их родители не видят применения и поэтому не воспринимают образование всерьез. Рассмотрим два прецедента, когда добросовестно внедряемая качественная система образования никак не помогала культурной колонизации и даже мешала ей.

Первым примером такого положения дел можно считать христианизацию Алтая, осуществляемую в XIX в. свт. Макарием (Глухаревым) и Макарием (Невским). Оба иерарха вели среди алтайских кочевников миссионерскую работу и по заведенной еще свт. Филофеем (Лещинским) традиции организовывали для местных мальчиков начальные школы. Но в ходе этой деятельности была допущена важная ошибка: святители старались убедить прозелитов из числа кочевников перейти к оседлому образу жизни и помогали новокрещенцам поселиться в одном из ближайших русских сел. В результате оседлое население Алтая стремительно увеличивалось, на месте так называемых миссионерских станов вырастали деревни со смешанным русскоалтайским населением, в которых обязательно были церкви и начальные школы, однако алтайцы, сохраняющие кочевой образ жизни, практически не оказались охвачены ни христианской проповедью, ни русской школой. В то время как перешедшие к оседлости местные жители стремительно «русели» (в начале XX в. на Алтае было немало клириков и мелких чиновников коренных национальностей), кочевники ощущали себя за бортом жизни и возлагали вину за это на русских пе- реселенцев. Итогом такого культурного раскола в начале XX в. стало религиозно-политическое движение получившее название бурханизм, социальной базой которого были исключительно алтайцы-кочевники [10, c. 234-248].

Другой пример бесполезности образования в процессе колонизации - попытка правительства США способствовать седентаризации индейцев Великих равнин, предоставив их детям бесплатное начальное образование. Культурно-политический конфликт, случившийся при попытке принудить кочевников-индейцев к оседлой жизни в резервациях, американские политики пытались разрешить, дав детям коренных американцев знания и манеры, полезные в социальной и экономической жизни американского общества. По замыслу конгрессменов, индейцев следовало отучать от кочевой жизни и приучать к оседлости с детства, и тогда через какие-нибудь 5-10 лет индейские племена без всякого принуждения превратятся в фермеров и рабочих. Для реализации этого плана были приглашены опытные учителя, но результат оказался прямо противоположным. Вот как описывает провал «педагогической экспансии» Ю.В. Стукалин: «В 18792. в Пайн-Ридж приехал Ричард Пратт, основатель знамени той школь для индейских детей - Карлайл. Его проект пользовался поддержкой не только властей, но и прессъ. Многочисленные публикачии изображали Пратта гуманистом, посвятившим жизнь маленьким дикарям в надежде сделать из них полноченных граждан страны. В действительности детей на несколько лет отрыьвали от семей, малейшие проступки, в число которых входили разговоры на родном языке, наказывались беспощадной поркой. Пратту удалось набрать из агентств Пайн-Ридж и Роузбад <... 60 мальчиков и 24 де вочки. Несколько месячев спустя, в июне 1880 г., делегаиия сиу посетила школу. Увиденное повергло индейщев в шок: коротко 
остриженные, в одинаковой синей форме, дети напоминали затравленных зверьков. Вождь брюле, не раздумывал, забрал собственных детей из этого ада. Пратт был возмущен, но его никто не слушал» [9, с. 226].

Была ли школа Ричарда Пратта действительно ужасной? Во второй половине XIX в. телесные наказания применялись практически во всех европейских и американских школах. $\mathrm{C}^{\circ}$ другой стороны, упомянутая синяя форма считалась признаком высокого статуса учебного заведения. Ведь читатель помнит, что персонажи Марка Твена, школьники из миссурийской глубинки, порой получали от учителя порку, но школьной формы им никто не выдавал. То есть Ричард Пратт попытался организовать обучение индейских детей по образцу престижной гимназии, но все его попытки провалились. И причиной этого фиаско была не бездарность или некомпетентность учителей, а несовместимость принятой в гимназии казарменной дисциплины с системой ценностей общества, из которого были набраны ученики. Педагогический эксперимент Пратта косвенно стал одной из причин, из-за которых индейцы вскоре утратили доверие к американским властям и консолидировались вокруг эзотерического и направленного против белых колонизаторов учения под названием Пляска Духа.

Итак, в данной работе мы рассмотрели роль образования в процессе колониальной экспансии. Какие важные черты этой роли мы могли бы выделить? Во-первых, это инструментальный характер применения образовательных учреждений и практик. Желая сделать население колонии лояльным к метрополии, субъекты колонизации с самых античных времен стремятся при помощи выверенных моделей воспитания и обучения формировать их картину мира. Во-вторых, хотя образование и применяется как вспомогательное средство политической и экономической колониальной экспансии, без экспансии культурной оно не приносит результатов. На примере исторических фактов мы видели, как, будучи составным компонентом процесса христианизации, школьное образование достаточно органично прижилось среди коренного населения Сибири в XVIII в. Наоборот, экономическая экспансия, осуществляемая французскими колонистами по отношению к чернокожим рабам на Гаити, не сопровождалась никакой культурной трансляцией. В результате за сто лет в колонии так и не сложилось единого общества, а изменение баланса сил сразу же привело к вооруженной борьбе и расправам. Однако применение образования в экспансионистском процессе имеет четкие границы. В частности, применяемое в отрыве от других компонентов культурной экспансии (религии, искусства) ни начальное, ни высшее образование не может, с нашей точки зрения, преодолеть культурный барьер, разделяющий учителей и учеников.

\section{Лumepamypa:}

1. Андриевич В.К. Краткий очерк истории Забайкалья с древнейших времен до 1762 г. М.: Вече, 2013. 288 c.

2. Буцинский П.Н. Заселение Сибири и быт первых ее насельников. М.: Вече, 2012. $320 \mathrm{c.}$

3. Головнев А.В. Феномен колонизации. Екатеринбург : Ур0 РАН, 2015. 592 с.

4. Ингрэм Дж.К. История рабства от древнейших до новых времен. М.: Либроком, 2011. 2-е изд. 344 с.

5. Миллер Г.Ф. История Сибири в 3-х т. Т. 2. М.: Изд-во АН СССР, 1941. 637 с.

6. Моммзен Т. История Рима. В 5 т. Т. 5. Кн. 8. Провинции от Цезаря до Диоклетиана. M. : ACT, 2002. 749 c.

7. Поселянин Е.Н. Русская церковь и русские подвижники XVIII в. СПб.: Изд-во И. Л. Тузова, 1905. 320 с

8. Сибирь в составе Российской империи / отв. ред. Л.М. Дамешек, А.В. Ремнев. М.: Новое литературное обозрение, 2001. 368 с. 
9. Стукалин Ю.В. Трубка мира и топор войны. М.: ЭНАС, 2009. 304 с.

10. Сулимов С.И., Черниговских И.В., Черных В.Д. Путь креста: специфика христианской миссии в Новое время. Воронеж: Воронежский ЦНТИ — филиал ФГБУ «РЭА» Минэнерго России, 2018. 275 с.

11. Шапталов Б.Н. Теория и практика экспансионизма: опыт сильных держав. М.: Либроком, 2009. $384 \mathrm{c}$

\section{Stanislav Sulimov}

Ph.D in Philosophy, Associate Professor, Voronezh State University,

Voronezh,sta-sulimov@ya.ru

\section{Education as an instrument of cultural expansion}

This work is devoted to the analysis of the role of school education in expansionist processes. Based on modern domestic studies, the author discovers the sense of expansion and defines colonialism as one of its types. Distinguishing between such forms of expansion as political, economic and cultural (religious proselytism refers to cultural expansion), the author believes that the organization of primary education in the colonies is a guarantee of the strength of the results of colonial expansion, in whatever form it takes place. However if the educational system being established does not harmonize with the cultural picture of the world of potential students, then its application will be useless. The author examines the application of school education in the process of colonization on a wide range of the examples - from the Siberia to the Indian reservations.

Keywords: expansion; colonization; the cultural picture of the world; Christianization; schooling; the Orthodox Church; slavery; sedentarization.

\section{Татьяна Шорина}

\section{Поликультурное образование сегодня: опыт Москвы и Санкт Петербурга}

В статье рассматриваются этапы становления и развития поликультурного образования в России, определяются актуальные направления и основные научные школы Москвы и Санкт-Петербурга. Автор описывает опыт двух российских столии в сфере продвижения поликультурного образования в школах, определяет вклад ученых и педагогов в развитие поликультурного образования РФ.

Ключевые слова: поликультурное образование; инофоны; дети мигрантов; глобализация; социокультурная адаптация; многонациональный; полиэтнический; школь русского языка.

К 80-летним юбилеям моих наставников Юрия Алексеевича Горячева и Ирины Павловны Лысаковой

Поликультурное образование и воспитание сегодня - неотъемлемая часть любого образовательного процесса в российской школе. С 2000 г. профессиональные интересы автора тесно связаны с проблемой полилингвального образования. Данная статья призвана отметить огромный вклад науч-
Шорина Татьяна

Александровна

кандидат педагогических наук ведущий научный сотрудник

Межвузовского чентра билингвального и поликультурного образования

Российский государственный педагогический университет им. А.И. Гериена

(Санкт-Петербург),

shorinatatiana@yandex.ru ных школ Москвы и Санкт Петербурга в формирование и развитие поликультурного образования Российской Федерации, а также проследить его истоки и этапы становления.

В научной литературе термин «поликультурное образование» определяется как образование, цель которого - подготовка молодого поколения XXI века к жизни в условиях многонациональ- 